\title{
Releasing Unweevilled White Pine to Ensure First-Log Quality of Final Crop
}

\author{
W. M. Stiell
}

Petawawa National Forestry Institute

Chalk River, Ontario

\begin{abstract}
A plantation of eastern white pine was established in 1939 on an old field, at the extremely close spacing of $0,66 \times 0,66 \mathrm{~m}$ in an attempt to limit the occurrence and severity of damage by the white pine weevil. A pre-commercial thinning at age 19 released selected crop trees, unweevilled within the first 5-m log, which have since grown well and should survive to maturity if periodically released. The untreated part of the plantation showed sustained heavy mortality from suppression, drastically reducing the numbers of unweevilled trees which were mostly in the lower crown classes. It was concluded that even a dense stand of white pine will retain only a negligible number of trees without weevil damage to the first log through to the final crop, unless some form of protection is provided, or release thinnings are started at an early age. Plantation establishment at very close spacings is not economic, but early release could be a feasible approach to managing dense natural stands of open-grown white pine.
\end{abstract}

\section{Résumé}

En 1939, une plantation de pins blancs fut établie dans un vieux champs à l'espacement très rapproché de $0,66 \times 0,66 \mathrm{~m}$ dans le but de réduire l'occurrence et la sévérité des dommages causés par le charançon du pin blanc. Une éclaircie prataiquée à l'àge de 19 ans a dégagé des arbres sélectionnés du peuplement final dont la première bille de $5 \mathrm{~m}$ était débarrassée du charançon. Ces arbres ont bien poussé et devraient survivre jusqu'à maturité moyennant un dégagement périodique. A cause de la dominance, plusieurs arbres sont morts dans la partie de la plantation n'ayant pas subi de traitement, ce qui a eu pour effet de réduire considérablement le nombre d'arbres débarrassés du charançon. Ces derniers se classaient surtout parmi les cimes basses. II fut donc conclu que même dans un peuplement dense de pins blancs, très peu d'arbres ne seront pas victimes du charançon dans leur premiere bille jusqu'a la récolte finale à moins de les protéger de quelque façon ou de les dégager par des éclaircies commencées très tôt. Des plantations à espacements trè rapprochés ne sont pas rentables mais un dégagement effectué très tôt apparaît comme étant une approche pratique dans l'aménagement de peuplements denses naturels pour récolter des pins blancs poussant de façon dégagés.

The influence of stocking level in stands of eastern white pine (Pinus strobus L.) on the incidence and severity of damage caused by the white pine weevil (Pissodes strobi Peck) has long been recognized, denser stands being less affected (Peirson 1922, Graham 1926, and MacAloney 1930). That high density becomes a liability in untended stands was demonstrated at the Petawawa Forest Experiment Station where a white pine plantation spaced at $0,66 \mathrm{x}$ $0,66 \mathrm{~m}$ (equivalent to about 22900 trees/ha) was established in 1939 on an old field (Stiell 1968). In 1958 when average stand height was $7,5 \mathrm{~m}$ and stocking still over 10000 trees/ha, ca. $60 \%$ of the trees had escaped weevil damage within the first $5-\mathrm{m} \mathrm{log}$, indicating initial success of the close-planting approach. However, the still dense stand was making very slow diameter growth, and intense natural competition was causing considerable mortality in the lower crown classes which contained most of the better-formed trees. In fact mortality was proceeding twice as fast in the unweevilled as in the weevilled trees (which included most of the dominants).
A pre-commercial thinning experimient, based on the general method described by Cline and MacAloney (1931, 1935), was initiated in the 19-year-old plantation with the object of releasing undamaged crop trees, mainly well-formed co-dominants. An untreated plot served as the control. By 1967 good response had been shown by the thinned stand in terms of faster diameter growth, and much lower mortality, than occurred on the control plot. In 1977 these effects were still evident (Table 1). All 370 designated and pruned crop trees per hectare had survived, and should persist to form the final crop if periodically released. Success of the treatment suggested that it might be adaptable to natural white pine regeneration where the dense stocking has occurred at no cost.

Nevertheless the tending method does incur costs without immediate return, and it is worthwhile examining whether or not sufficient well-formed trees might survive to maturity in an untreated stand. Past development of the control plot as well as other data are used in the following analysis.

Survival of the control has shown a remarkably uniform decline since planting to its present level of $18 \%$, representing an average failure rate of $2.1 \%$ of initial numbers, or a periodic annual rate of about $4 \%$ (Fig. 1 ). If this rate is maintained, numbers at age 100 years will be reduced to $277 /$ ha. As shown in Table 1, mortality was heaviest among the smaller trees; in fact for each of the past two decades $96 \%$ was in the median and lower diameter classes. The combined result has been to reduce the numbers of unweevilled trees from about $9500 /$ ha in 1951 to about 149 /ha in 1977 , which included $10,2 \%$ of all trees above mean dbh.

On the basis of permanent sample plot records of natural pine stands at Petawawa, it is estimated that the control plot at age 100 will have approximately $35 \%$ of its trees larger than mean $\mathrm{dbh}$, or $97 / \mathrm{ha}$. These will include $10,2 \%$ or 10 unweevilled trees/ha. If very minor weevil damage can be accepted, i.e. stems with partially grown-over dead leaders but with no perceptible crook in the first $5-\mathrm{m}$ log, then the total of "undamaged" trees would still be no more than $30 /$ ha. For an untended, unprotected stand these values could only be greater if initial stocking were much higher. Such a condition would be rare, since a density of about 23000 established seedlings per hectare (equivalent to this stand at planting) seems well above average for natural white pine reproduction, although the maximum may be in the neighbourhood of $50000 /$ ha (Fisher and Terry 1920, Pierson 1922, MacAloney 1930, Hawley 1936, Fraser and Farrar 1955, Lutz and Cline 1956, Horton and Bedell 1960). It appears, then, that even a dense stand of white pine established in the open will, if untreated, only retain a negligible number of trees without weevil damage in the first 5-m log through to the final crop.

If the need for thinning to retain sufficient undamaged trees for the final crop is accepted, then the timing of this operation may be important. The earliest would be when the majority of trees have reached a height of $5 \mathrm{~m}$, when an am- 


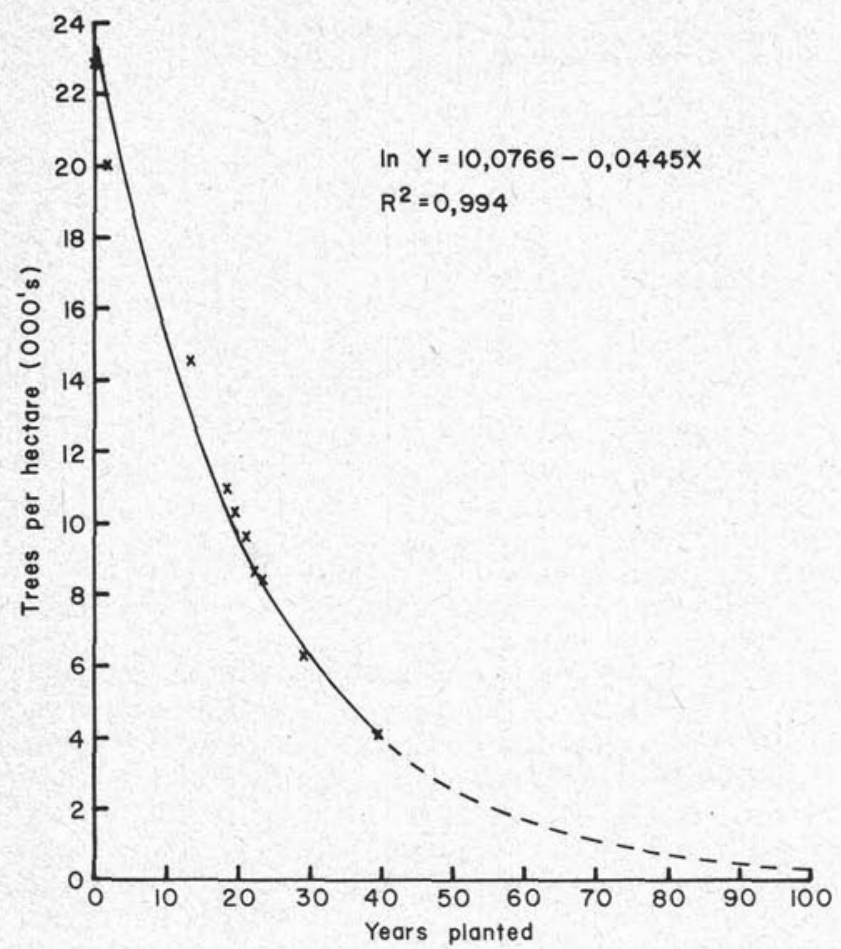

Fig. 1. Mortality on control plot.

\begin{tabular}{|c|c|c|c|c|}
\hline \multirow{2}{*}{$\begin{array}{c}1967 \text { dbh class } \\
(\mathrm{cm})\end{array}$} & \multicolumn{2}{|c|}{$\begin{array}{l}\text { Growth } \\
\text { (cm) }\end{array}$} & \multicolumn{2}{|c|}{$\begin{array}{c}\text { Mortality } \\
(\%)\end{array}$} \\
\hline & Control & Thinned & Control & Thinned \\
\hline 6 & - & 0,46 & 100 & 22 \\
\hline 8 & 0,53 & 1,07 & 67 & 1 \\
\hline 10 & 1,02 & 2,90 & 22 & 14 \\
\hline 12 & 1,73 & 4,29 & 8 & 3 \\
\hline 14 & 2,21 & 5,33 & 2 & 4 \\
\hline 16 & 2,90 & 5,89 & 0 & 5 \\
\hline 18 & 3,68 & 5,82 & 0 & 0 \\
\hline 20 & 3,73 & 6,55 & 0 & 0 \\
\hline 22 & 3,86 & 7,29 & 0 & 0 \\
\hline 24 & 4,06 & - & 0 & - \\
\hline
\end{tabular}

ple supply of stems with undamaged first logs from which to select would be available, and thinning operations would be at their easiest. Drawbacks at this stage would be uncertainty of continued vigour of the trees selected, and the possibility that they might be subject to severe weevil attacks which could curtail height growth although of course could not affect the quality of the first log.

The latest that a first release thinning could be applied would be when numbers of unweevilled trees had fallen close to the required minimum, say 370 crop trees per hectare. This stage was not identified in this study, but from trends of mortality and damage it probably occurred between 1970 and 1975. Deferment of treatment in this way would allow a commercial thinning and diminish risks of sun scorch, but growth response would be slow because of short crowns and distribution of the undamaged trees within the stand might not be satisfactory.

\section{References}

Cline, A. C., and H. J. MacAloney. 1931. A method of reclaiming severely weevilled white pine plantations. Mass. For. Assoc. Bull. 152. $11 \mathrm{p}$.

Cline, A. C., and H. J. MacAloney. 1935. Progress report of the reclamation of severely weevilled white pine plantations. J. For. 33(1): 932-935.

Fisher, R. T., and E. I. Terry. 1920. The management of second growth white pine in central New England. J. For. 18(4): 358-366.

Fraser, J. W., and J. L. Farrar. 1955. Strip-cutting in a mixed pine stand. Can. Dep. North. Aff. Natl. Resour., For. Branch, For. Res. Div. Tech. Note 1. 17 p.

Graham, Samuel A. 1926. Biology and control of the white-pine weevil, Pissodes strobi Peck. Cornell Univ. Agric. Exp. Stn. Bull. 449. $32 \mathrm{p}$.

Hawley, Ralph C. 1936. Observations on thinning and management of eastern white pine (Pinus strobus Linnaeus) in southern New Hampshire. Yale Univ., School For. Bull. 42. 16 p.

Horton, K. W., and G. H. D. Bedell. 1960. White and red pine: ecology, silviculture and management. Can. Dep. North. Aff. Natl. Resour., For. Branch Bull. 124. 185 p.

Lutz, R. J., and A. C. Cline. 1956. Results of the first thirty years of experimentation in silviculture in the Harvard Forest, 1908-1938. Part II. Natural reproduction methods in white pinehemlock stands on light, sandy soils. Harvard For. Bull. 27. 70 p.

MacAloney, Harvey, J. 1930. The white pine weevil (Pissodes strobi Peck) - its biology and control. N.Y. State Coll. For. at Syracuse Univ., Tech. Publ. 28. 87 p.

Peirson, H. B. 1922. Control of the white pine weevil by forest management. Harvard For. Bull. 5. 42 p.

Stiell, W. M. 1968. Thinning technique improves quality of white pine stands. Can. For. Ind. 88(3): 54-56. 